УДК 811'243:37.091.33-027.22

DOI: $10.24144 / 2617-3921.2019 .17 .223-230$

Наталія Годованець кандидат філософських наук,доцент дочент кафедри іноземних мов ДВНЗ «Ужсгородський національний університет» ORCID 0000-0003-3429-6973 м.Ужггород, Україна nataliia.hodovanets@uzhnu.edu.ua, тел.0958789075

Вікторія Леган викладач кафедри іноземних мов ДВНЗ «Ужсгородський національний університет» ORCID 0000-0003-0222-3120 м.Ужггород, Украйна viktoriya.lehan@uzhnu.edu.иа, тел.0508849380

\title{
Рольова гра як один з активних методів навчання іноземної мови
}

Анотація. У статті розглянуто рольову гру як один із методів активного навчання іноземній мові. Проаналізовано класифікації та моделі методів навчання, а також описано сучасні технології навчання. 3і статті стає зрозумілим, що перевагою активного навчання $\epsilon$ використання попереднього досвіду, нові перспективи,відкритість по відношенню до результатів навчання та взаємопідтримка і взаємонавчання. Саме рольова гра як групова форма навчання, у прочесі якої використовується рольова структура ведення заняття, тобто набір ролей, які регламентують діяльність $і$ поведінку студентів- відіграє важливу роль в активізації навчально-виховного прочесу пізнавально-оцінювальної та практичної діяльності учасників заняття. Саме ией активний метод ставить їх у ситуацію, що включає ті ж обмеження, мотивачію, що існують у реальному cвimi.

Ключові слова: активні методи навчання, ситуачія, рольова гра, студент, іншомовна компетенція .

Abstract. In a given article the role play is considered as one of the methods of active teaching of a foreign language. Classification and models of teaching methods are analyzed, and modern teaching technologies are described. From the article, it becomes clear that the advantage of active learning is the use of prior experience, new perspectives, openness to learning outcomes,mutual support and mutual learning. It is a role-play game as a group form of learning, in which the role structure of the class is used, that is, a set of roles that regulate the activities and behavior of students-plays an important role in activating the educational 
process of cognitive-evaluative and practical activity of participants in the class. It is this active method that puts them into a situation that includes the same restrictions, motivations that exist in the real world.

Keywords: active methods of studying, situation, role-play, student, foreign competence.

Актуальність досліджуваної теми визначається тим що головним напрямом розвитку сучасної освіти України є підвищення рівня вивчення іноземної мови. Високі вимоги до оволодіння іноземною мовою зумовлюють пошук вчителями, викладачами нових сучасних методів, прийомів та технологій навчання, використання яких у процесі формування іншомовної комунікативної компетенції молоді було б ефективним.

Вступ. Виходячи $з$ того, що навчальний процес будується на основі взаємодії викладача і студента, викладач може обрати одну із форм навчання, які, наприклад, О. Журавльова поділяє на пасивні (викладач $є$ основною діючою особою і керує ходом заняття, а студенти виступають у ролі пасивних слухачів), активні (студенти є активними учасниками і мають однакові права 3 викладачами) та інтерактивні (взаємодія студентів відбувається не тільки з педагогом, але і між собою; активність студентів у навчальному процесі є домінуючою) [5]. Необхідність активного навчання це сучасні освітні тенденції, де студент постає суб'єктом навчального процесу у ході спілкування з викладачем, виконавцем комунікативних, творчих та пошукових завдань. Методи активного навчання передбачають використання такої системи методів, яка спрямована головним чином не на викладання готових знань і їх відтворення, а на самостійне оволодіння студентами знань в процесі активної пізнавальної діяльності [9].

Метою статті $є$ дослідження активних методів навчання іноземної мови для підвищення ефективності ії вивчення.

Аналіз психолого-педагогічних джерел довів, що вивченням комунікативно-спрямованих методів та технологій займались багато зарубіжних та вітчизняних науковців, таких як Й. І. Пасов, І. А. Зязюн, П. К. Анохін, А. Н.Леонтьєв, Джон та Ліз Соарз та інші. Свій вклад в розвиток активних методів навчання внесли А.Астахова, Л.Гурч, І.Дичківська, та інші. Але дані дослідження проводились в основному на шкільному навчанні.

Треба відзначити, що І.Дичківська в своїх роботах не тільки обгрунтувала необхідність використання активних методів у всіх видах навчальної роботи студентів, але і ввела поняття діалогічного проблемного навчання як найбільш повно передаючого сутність процесів спільної діяльності викладачів і студентів, а також їх взаємної активності в рамках «суб'єкт-суб'єктивних» відносин [4,с.44].

Методи та методологія проведення дослідження. Для вивчення та розуміння рольової гри як одного з активних методів навчання існує низка 
методів та підходів, які допомагають краще зрозуміти та дослідити це явище. У процесі дослідження ми послуговувались методами дескриптивного аналізу та узагальнення, синтезу, а також соціальним, психологічним та когнітивним підходом. За допомогою цих методів ми визначили що рольова гра - це ефективна навчальна методика, але вона має бути добре продумана i організована, щоб забезпечити позитивний вплив на учасників. В її структуру органічно входить з'ясування мети, планування, реалізація мети, а також аналіз результатів, у яких особистість цілком реалізує себе як суб'єкт. Також визначено особливості рольової гри.

Виклад основного матеріалу. На сучасному етапі розвитку методики вивчення іноземної мови основний акцент робиться на розвитку особистісно орієнтованого та комунікативного підходів. Необхідно відзначити, що для успішного активного засвоєння студентами знань, умінь, навичок придатні не всі методи навчання, а лише ті, які з одного боку, створювали б дидактичні й психологічні умови для спонукання до самостійної діяльності, а з іншого боку моделювали б предметний зміст майбутньої професійної діяльності студентів. На нашу думку, таким вимогам відповідає активне навчання.

Під активним навчанням $\mathrm{H}$. Буркіна пропонує розуміти «таку організацію та ведення навчального процесу, яка направлена на всебічну активізацію навчально-пізнавальної та практичної діяльності студентів у процесі засвоєння навчального матеріалу за допомогою комплексного використання як педагогічних, так і організаційних засобів» [1, с. 36].

До класифікації активних методів навчання існують різні підходи. В.Н. Кругликов наголошує, що за відмінні ознаки використовують:

- характер навчально-пізнавальної та ігрової діяльності;

- ступінь активізації студентів;

- спосіб організації ігрової взаємодії;

- місце проведення занять, їх цільове призначення;

- імітаційна модель, що використовуєтьсяі багато інших [8].

Найчастіше використовують класифікацію А.М. Смолкіна, а саме за характером навчально-пізнавальної та ігрової діяльності. Відповідно даної класифікації методи активного навчання поділяють на:

1. Імітаційні методи, які базуються на імітації професійної діяльності. Вони в свою чергу поділяються на:

а) ігрові методи:

- ігрові процедури і прийоми - засоби реалізації окремих, одиничних принципів, в першу чергу, різні форми активізації лекцій i iнших традиційних форм навчання, ігрові педагогічні прийоми, окремі засоби активізації. Наприклад, ті, що реалізовують принцип проблемної лекції $з$ використанням методу аналізу конкретних ситуацій у вигляді ілюстрації, здійснюваної викладачем, лекція із запланованими помилками, лекція удвох, проблемна лекція, творче завдання, лекція прес-конференція, лекціядискусія, лекція-бесіда (принцип діалогового спілкування) тощо; 
- ігрові ситуації, прикладом яких можна вважати дискусійнізаняття, що проводяться вигляді незапланованих виступів, коли заздалегідь невідомо хто і в якому статусі (доповідача, критика, провокатора) братиме 3 участь в обговоренні. Також ігрові ситуації використовують для ролевих, театралізованих ігор, спрощених управлінських тренінгів тощо;

- дидактична або навчальна гра - в основі якої використовується ігрова ситуація, але діяльність учасників формалізована, тобто є правила, жорстка система оцінювання, передбачений порядок дій, регламент тощо;

- ділові ігри - методи, що реалізовують всю сукупність елементів, а, отже, і весь комплекс принципів активізації, характерних для методів активного навчання;

б) неігрові методи - аналіз виробничих ситуацій, аналіз конфліктів, аналіз проблемних ситуацій, аукціон ідей, імітаційні вправи, диспути, мозкова атака, опорні сигнали, взаємо опитування, аналіз конкретних ситуацій, розбір ділової пошти керівника, дії по інструкції тощо.

2. Неімітаційні методи - стажування на робочому місці, програмоване навчання, проблемна лекція, випускна робота. За призначенням виділяють неімітаційні методи за:

- мотивацією пізнавальної діяльності;

- повідомленням навчальної інформації;

- формуванням і вдосконаленням професійних умінь і навичок;

- освоєнням передового досвіду, контроль результатів навчання [10, c.32-38].

Методи активного навчання можуть використовуватися на різних етапах навчального процесу:

Перший етап - первинне оволодіння знаннями. Це можуть бути проблемна лекція, евристична бесіда, навчальна дискусія тощо.

Другий етап - контроль знань, умінь та навичок (закріплення), можуть бути використані такі методи як колективнарозумова діяльність, тестування тощо.

Третій етап - формування професійних умінь та навичок на основі знань і розвиток творчих здібностей, можливо використання модельованого навчання, ігрових і неігрових методів [10, с. 41-43].

B. I. Чупрасова, спираючись на визначення активних методів навчання як методів, що сприяють організації пізнавальної діяльності студентів, пропонує таку класифікацію методів активного навчання:

а) комунікативні методи (групові дискусії, лекції, проблемні ситуації);

б) ігрові методи (дидактичні ігри, рольові, ділові ігри);

в) конструктивні (проблемне навчання, програмоване навчання);

г) корекційні методи (аутотренінг, ігрова психотерапія, психодраматична корекція) [12].

Основними перевагами активних методів навчання $\epsilon$ :

- підвищення мотивації в процесі навчання; 
- використання попереднього досвіду;

- нові перспективи;

- критичне переосмислення існуючих припущень;

- відкритість по відношенню до результатів навчання;

- взаємопідтримка і взаємонавчання;

- заохочення до самостійної роботи і відповідальності до результатів навчання;

- розвиток загальних комунікативних навичок (прослуховування, обговорення, співпраця)

Основними недоліками у використанні активних методів навчання $є$ :

- брак часу;

- готовність студентів і викладача використовувати активні методи;

- емоційні ризики, наприклад при проведенні рольових ігор.

Однією $з$ сучасних педагогічних технологій, яку використовують у освітньому процесі, $є$ імітаційно-моделюючі (ігрові, арт-ігрові) технології. Ефективність навчання значною мірою залежить від зацікавленості студентів, мотивації, яка стимулює їхню активну діяльність. Будь-яка гра вимагає дотримання певних правил та винахідливого їх використання. У процесі виконання рольових ігор створюються оптимальні умови для розвитку творчого мислення.

Навчальна гра позитивним чином відрізняється від інших методів навчання тим, що дозволяе студентам бути причетними до розробки теми, яку вивчають, спробувати свої сили в конкретних життєвих ситуаціях. Саме під час гри розвиваються навички аудіювання, закріплення лексики на основі раніше вивчених правил, збільшується діапазон лексики за фахом.

Рольова гра - це групова форма навчання, у процесі якої використовується рольова структура ведення заняття, тобто набір ролей, які регламентують діяльність і поведінку студентів. Рольова гра відіграє важливу роль в активізації навчально-виховного процесу. Це досягається активізацією пізнавально-оцінювальної та практичної діяльності учасників заняття, певною організацією їх взаємодії та спілкування.

Рольова гра - це один 3 методів ситуативного характеру навчання іноземним мовам, тобто навчання, що передбачає моделювання реальних ситуацій, з якими можна зіткнутися в житті. О.Б. Тарнопольський надає наступне визначення рольової гри як «виду навчальної діяльності, в якій учасники діють та спілкуються у межах обраних ними / заданих їм ролей, керуючись характером обраної ролі та логікою ситуації і середовища діяльності. Сюжет розгортання гри та іiі ціль можуть або задаватися заздалегідь, або поступово розвиватися самими учасниками гри в іiї процесі. При цьому, в межах заданих обмежень та правил (ролі, ситуації, сюжет та цілі, якщо вони задаються, і т.д.) гравці вільні щодо застосування можливих імпровізацій, які стосуються ходу гри, ії розвитку, напрямку цього розвитку тощо» [11]. 
Для ефективного спілкування учасники рольової ігри повинні дотримуватися обов'язків та відповідності їх ролей та функцій, та якомога найкраще проявляти себе в ситуативному мовленні. По відношенню один до одного студенти мають використовувати свої особисті комунікативні здібності [2].

Організаційною одиницею рольової гри є ситуація, що «розігрується». Вона розгортається в процесі заняття як окремий сюжет. В основу такого сюжету може бути покладена навчальна або реальна життєва проблема, встановлюється необхідний і достатній набір ролей (учасників ситуації), які розподіляються між учасниками. Кожен учасник гри, має виконати певну роль, дотримуючись рольових приписів протягом усієї гри [6].

Діяльність викладача залежить від складності рольової ігри. За допомогою рольової гри викладач може розвивати усі види мовленнєвої діяльності студентів, i, перш за все усне мовлення.

Метод рольових ігор повинен відповідати чотирьом критеріям: зміст $є$ найголовнішим; існує мета, яка повинна бути досягнута в процесі; діяльність оцінюється за результатами; між студентами існують реальні стосунки. Таким чином увага в аудиторії фокусується не лише на мові, але й на цілях і видах діяльності, які можуть визначатися викладачем або студентами. Креативні рольові ігри стимулюють студентів використовувати власну фантазію, спонукають їх думати і говорити [2].

Як зазначає Л.М. Карамушка, у сучасній психолого-педагогічній науці існують різні класифікації рольових ігор. Однією з можливих, на ії думку, $є$ класифікація використовуваних завдань та ролей. Відповідно до неї розрізняють навчально-рольові та ділові ігри. Основне призначення рольових ігор полягає в тому, щоб забезпечити всебічний та глибокий аналіз тієї чи іншої проблеми, використовуючи так звані навчальні ролі. Ділова гра спрямована на те, щоб, імітуючи реальні ділові (професійні, побутові тощо) ситуації, виконуючи справжні, а не навчальні ролі, студенти набували умінь та навичок, необхідних для виконання різних видів практичної діяльності [6, c. 788$]$.

Рольова гра відбувається у кілька етапів. Спочатку викладач повідомляє тему, мету, інформує учасників про зміст кожної ролі, після чого створюються рольові групи. Далі відбувається опановування ролей $\mathrm{i}$ 3'ясування суті питання чи ситуації. Протягом наступного етапу учасники гри готуються до обговорення проблеми чи програвання ситуації. У міру готовності студентів починається етап обговорення проблеми або програвання «реальної» ситуації. Послідовно слово мають різні рольові групи, які висловлюють свою позицію щодо проблеми яка аналызуэться, або ж моделюють виконання необхідних дій. Упродовж гри викладач визначає смислову лінію аналізу теоретичної проблеми або практичної ситуації, порушує додаткові питання та ставить завдання. Він заохочує всіх студентів до гри в атмосфері доброзичливості, взаємодопомоги, рівноправності. 
Викладач завершує заняття підбиттям підсумків, наголошуючи на змісті та реалізованості задуму [7].

Рольова гра $є$ одним з тих унікальних методів навчання, що допомагає студентам справлятися 3 невизначеністю. Рольова гра ставить їх у ситуацію, що включає ті ж обмеження, мотивацію, що існують у реальному світі; іiі можна використовувати в багатьох навчальних ситуаціях, у процесі вивчення багатьох навчальних дисциплін. Особлива увага приділяється рольовій грі в процесі вивчення іноземної мови.

О.М. Діанова, Л.Х. Костіна на основі огляду зарубіжної методичної літератури відрізняють наступні особливості рольової гри:

- рольова гра - це навчання в дії. Вона сприяє підвищенню якості навчання;

- рольова гра вимагає повної віддачі від учасників, їх реакції як вербальними, так і невербальними засобами в заданій ситуації;

- рольова гра $\epsilon$ мотивуючою, оскільки містить елемент гри й непередбачуваність розв'язки. Студенти бачать можливість застосування ситуації, що програється в рольовій грі, у реальному житті;

- рольова гра дає студентам «підказку» - якими одиницями, і якими мовними моделями можна виразити ту або іншу думку в даній ситуації залежно від заданої характеристики учасників;

- рольова гра несе в собі елемент несподіванки («момент шоку»). У процесі рольової гри учасники повинні уважно слухати один одного, швидко думати й адекватно реагувати на репліки своїх товаришів;

- протягом рольової гри відбувається емоційний підйом;

- рольова гра має переваги перед іншими прийомами й методами навчання, тому що в ній беруть участь всі учасники, і вона дає можливість легше виразити свою думку, знаходячись «під маскою» діючої особи [3].

Ігрові методи надають відчуття реальності навчальної гри, що, у свою чергу, підвищує серйозність запропонованої ситуації та мовленнєву активність студентів під час обміну думками та поглядами у контексті обговорення та вирішення певної проблеми. Молоді люди запам'ятовують слабко, якщо навчання не захоплює їх. Тому саме 3 метою активного засвоєння знань необхідно перетворити заучування матеріалу на захопливу гру.

Висновки. Отже, можна зробити висновок, що активні методи навчання направлені на перебудову і вдосконалення навчально-виховного процесу та підготовку фахівців до професійної діяльності. Вони створюють необхідні умови для формування і закріплення знань, умінь та навичок; для розвитку вмінь самостійного мислення, орієнтування у новій ситуації; знаходження підходів до вирішення проблеми. Запровадження активних методів у навчальний процес надасть можливості: підвищити емоційний відгук студентів на процес пізнання, посилити мотивацію навчальної діяльності, сприятимуть розвитку творчих здібностей студентів, усного 
мовлення; висловлювати власну точку зору, активують мислення тощо. Рольові ігри позитивно впливають на навчання студентів іноземним мовам. Вони сприяють засвоєнню лексичного матеріалу, покращенню навичок усного мовлення та вміння швидко реагувати у стресових ситуаціях, що в свою чергу виокремить студента серед значної кількості випускників. Подальші дослідження передбачають дослідження й впровадження методів активного навчання у навчально-виховний процес підготовки фахівців різних галузей.

\section{ЛIТЕРАТУРА}

1. Буркіна Н. Використання активних методів навчання в дистанційних курсах. Теория и методика электронного обучения. Кривий Ріг: КНУ, 2012. C.35-39.

2. Горген А. Рольові ігри як метод навчання іноземної мови http://www.rusnauka.com/35_OINBG_2012/Pedagogica/5_121861.doc.htm. 19.06.2019

3. Дианова Е., Костина Л. Ролевая игра в обучении иностранному языку:Обзор зарубежной методической литературы. Иностранные языки в школе. Москва: Просвещение , 2005. С.90-92.

4. Дичківська I. Інноваційні педагогічні технології. Київ:Академвидав, 2004. 352c.

5. Журавлева О. Практическая реализация интерактивных методов обучения в электронной образовательной среде на примере e-learning lms black board. Чебоксары: ЦНС «Интерактив плюс», 2015. 334c.

6. Карамушка Л. Рольова гра. Київ : Юрінком Інтер, 2008. 104c.

7. Киливник В. Рольова гра як один 3 методів активного навчання студентів іноземній мові http://umo.edu.ua/images/content/nashi_ vydanya/stud_almanah/21.pdf. 20.06.2019

8. Кругликов В. Активное обучение в техническом вузе (теоретикометодологический аспект). Дис., Санкт-Петербург, 2000.424c.

9. Панина Т. Современные способы активизации обучения. Москва: "Академия", 2008. 176с.

10.Смолкин А. Методы активного обучения. Москва: Высшая школа, 1991. 176c.

11.Тарнопольський О. Методика навчання іншомовної мовленнєвої діяльності у вищому мовному закладі освіти. К.: Фірма "Інкос", 2006. $248 \mathrm{c}$.

12.Чупрасова В. Деловая игра как средство формирования психологического климата в студенческой группе. Дис., СанктПетербург: СпбГУ 1991. 224c. 